\author{
Asian Journal of \\ Medical and Biological Research \\ ISSN 2411-4472 (Print) 2412-5571 (Online) \\ www.ebupress.com/journal/ajmbr
}

\title{
Article Changes in hepatosomatic index and histoarchitecture of liver in common carp
exposed to organophosphate insecticide sumithion
} Sabrina Hossain ${ }^{1}$, Md. Idris Miah ${ }^{1}$, Md. Sadiqul Islam ${ }^{2}$ and Md. Shahjahan ${ }^{1, *}$

${ }^{1}$ Department of Fisheries Management, Bangladesh Agricultural University, Mymensingh-2202, Bangladesh

${ }^{2}$ Department of Fisheries Biology and Genetics, Bangladesh Agricultural University, Mymensingh-2202, Bangladesh

*Corresponding author: Department of Fisheries Management, Bangladesh Agricultural University, Mymensingh-2202, Bangladesh. E-mail: mdshahjahan@bau.edu.bd

Received: 10 May 2016/Accepted: 31 May 2016/ Published: 30 June 2016

\begin{abstract}
Sumithion is widely used in larval rearing aquaculture ponds to control aquatic insects. This experiment was carried out to evaluate the effect of sumithion on hepatosomatic index and liver morphology in common carp, Cyprinus carpio. Acute toxicity of sumithion (96 h LC50 value) was first determined and it was $8.05 \mathrm{ppm}$ for common carp. The fish were exposed to two sub-lethal concentrations $(0.85$ and $1.7 \mathrm{ppm})$ of sumithion for a period of 21 days. A control set was also run for the same time with the same number of fish without sumithion $(0 \mathrm{ppm})$. There was a marked increase in the hepatosomatic index in both concentrations $(0.85$ and $1.70 \mathrm{ppm})$ compared to control $(0 \mathrm{ppm})$. Several histological changes of liver, such as necrosis, patchy degeneration, degenerated hepatocytes, vaculation and blood spilling were observed after exposure to sumithion with dose and exposure time dependent manner. The present investigation revealed the toxic potentiality of sumithion on common carp which alters liver morphology that may lead metabolic changes in fish.
\end{abstract}

Keywords: environment; pesticide; fish; toxicology; histology

\section{Introduction}

In the last few decades, indiscriminate use of insecticides has raised the risk of contamination of environment as well as aquatic habitat. Though they have been used for the safety of humans, their harmful effects on other non-target animals like fish are alarming. Contamination of water by insecticides, either directly or indirectly can lead to fish kills, reduced fish productivity (Talukdar et al., 2012; Rahman et al., 2012). The insecticides in the aquatic environments can affect the aquatic organisms through changes in normal behavior and physiological functions (Ventura et al., 2008; Salam et al., 2015; Sharmin et al., 2015; Shahjahan et al., 2016). In Bangladesh, more than 300 types of insecticides are used for crop protection in agriculture (Uddin et al., 2016). Among them, sumithion, the O, O Dimethyl O-(3-methyl-4-nitrophenyl) is important one which falls under the organophosphate groups. In aquaculture, it is widely used in larval rearing pond to control harmful aquatic insect, tiger bug. However, sumithion is considered somewhat toxic to fish (Thomson, 1989). Therefore, it is very important to know the extent of damage made by this chemical to fish.

Histopathological studies are useful tools to assess the effects of toxicants on fish (Pimpao et al., 2007; Ahmed et al., 2015), widely used asbiomarkers in the evaluation of the health of fish exposed to contaminants, both in the laboratory (Thophon et al., 2003) and field studies (Teh et al., 1997). Among the different organs, liver is very important which are responsible for vital functions, such as accumulation and biotransformation of xenobiotics in the fish (Gernhofer et al., 2001). Hence, an effort was made to examine the effects of sumithion on the common carp (Cyprinus carpio), an economically important freshwater fish species contributing significant part in aquaculture for its high growth rate and palatability, by analysis of changes of hepatosomatic index (HSI) and liver histology. 
2. Materials and Methods

\subsection{Animals and chemicals}

The fish used in the present study and their maintenance in the laboratory have been previously described in details (Salam et al., 2015). In brief, the fish was collected from local fish farm and maintained in aquaria at 25 $\pm 0.5^{\circ} \mathrm{C}$ under a controlled natural photo-regimen $(14 / 10 \mathrm{~h}$, light/dark) for a period of 21 days before the experiments. The length and weight of fishes ranged from 17 to $19 \mathrm{~cm}$ and 75 to $90 \mathrm{~g}$, respectively. The fish were fed twice a day. The experimental procedures followed the guidance approved by the Animal Care and Use Committees of Bangladesh Agricultural University, Mymensingh, Bangladesh. To conduct the present experiment, sumithion $(60 \mathrm{E} / \mathrm{C})$ was collected from retail pesticide shop from local market.

\subsection{Determination of acute toxicity}

Acute toxicity was performed according to the standard method to determine the $96 \mathrm{~h}$ lethal concentration values (LC50) of sumithion. Six different concentrations $(2,4,6,8,10$, and $12 \mathrm{ppm}$ ) of sumithion with three replicates were used in the test series. Control units with three replicates were also prepared. Exceeding aeration was applied to the aquarium for $2 \mathrm{~h}$ in order to obtain a homogeneous concentration of the toxic compound, and then 10 fish were transferred into each aquarium. Mortality was assessed at 24, 48, 72, and $96 \mathrm{~h}$ after the start and dead fishes were removed immediately.

\subsection{Experimental design and sample collection}

To conduct the experiment nine aquaria $(75 \mathrm{~cm} \times 45 \mathrm{~cm} \times 45 \mathrm{~cm})$ were first cleaned and washed thoroughly by tap water. Then the aquaria were filled with $100 \mathrm{~L}$ of tap water. The experiment was conducted with three treatments, each with three replications. Two sub-lethal concentrations $(0.85$ and $1.70 \mathrm{ppm})$ were selected considering the $96 \mathrm{~h} \mathrm{LC50}(8.05 \mathrm{ppm})$ value. A control set was also run for the same time and with the same number of fish but without sumithion. Ten fish were transferred in each aquarium. To collect liver fish were sacrificed at 7, 14 and 21 days after start of exposure. Collected liver was preserved in 10\% formalin until use for sectioning. Hepatosomatic index $(\mathrm{HSI})$ was calculated as HSI $=($ Liver weight $(\mathrm{g}) /$ Fish weight $(\mathrm{g})) \times 100$.

\subsection{Histology of liver}

The fixed liver samples were passed through graded alcohol series to dehydrate them. The dehydrated liver samples were embedded into paraffin. Sectioning was done using microtome machine. The liver sections were then stained with hematoxylene-eosin stain. Finally the liver sections were observed under microscope and taken photograph.

\subsection{Statistical analysis}

Values are expressed as means \pm standard error of means (SEM). Data were analyzed by one-way analysis of variance (ANOVA) followed by Tukey's post hoc test to assess statistically significant differences among different treatments. Statistical significance was set at $\mathrm{P}<0.05$. Statistical analyses were performed using PASW Statistics 18.0 software (IBM SPSS Statistics, IBM, Chicago, USA).

\section{Results and Discussion}

\subsection{Acute toxicity of sumithion in common carp}

Table 1 summarizes the mortality patterns in relation to sumithion dosages. No mortality was taken place in control samples. The $96 \mathrm{~h}$ LC50 was calculated by probit analysis (Figure 1). The LC50 value of sumithion for common carp during the $96 \mathrm{~h}$ of exposure was $8.05 \mathrm{ppm}$. The determined $96 \mathrm{~h}$ LC50 value of common carp in the present study is less than the values of $11.8 \mathrm{ppm}$ for Heteropneustes fossilis and $15.3 \mathrm{ppm}$ for Gila elegance (Durkin, 2008; Faria et al., 2010). In contrast, lower 96 h LC50 value (2.2 ppm) was recorded for Oreochromis niloticus (Pathiratne and George, 1998). The variation in the toxicity of the pesticides may be attributed mainly to the susceptibility of the test animals and factors like $\mathrm{pH}$ and hardness of water.

\subsection{Effects of sumithion on hepatosomatic index (HSI)}

In the present study, HSI of common carp were calculated after exposed to sumithion (Figure 2). There was a noticeable increase in the HSI in both concentrations $(0.85$ and $1.70 \mathrm{ppm})$ compared to control $(0 \mathrm{ppm})$. The values of HSI were found increasing gradually at 7,14 and 21 days of exposure (Figure 2). The results were statistically analyzed and found to be significant $(\mathrm{P}<0.05)$ in higher concentration $(1.70 \mathrm{ppm})$ compared to control $(0 \mathrm{ppm})$. The liver plays an important role in the fat metabolism. It is already known that fat accumulated in the liver during poisoning (White et al., 1973). Conversion of glycogen to glucose has been demonstrated during pesticide toxicity in several fish species (Maheswari Devi et al., 1991). In our previous 
study, we demonstrated increased glucose level in this fish species exposed to sumithion (Hossain et al., 2015; Salam et al., 2015) and Malathion (Sharmin et al., 2015). Therefore, increases the HSI in the present study may be due to several changes in liver caused by the toxicity of sumithion. Increase in HSI has been reported in rats and mice exposed to dieldrin (Kolaja et al., 1996) are the good agreement of our study.

Table 1. Number of dead specimens and their percentage of mortality (in parentheses) in different concentrations of sumithion at different time intervals.

\begin{tabular}{lllll}
\hline Concentration $(\mathbf{p p m})$ & \multicolumn{4}{r}{ Exposure time (hours) } \\
\cline { 2 - 5 } & $\mathbf{2 4}$ & $\mathbf{4 8}$ & $\mathbf{7 2}$ & $\mathbf{9 6}$ \\
\hline Control $(0.0)$ & - & - & - & - \\
2.0 & - & - & - & - \\
4.0 & - & - & $3(10 \%)$ & $6(20 \%)$ \\
6.0 & - & $3(10 \%)$ & $6(20 \%)$ & $9(30 \%)$ \\
8.0 & - & $3(10 \%)$ & $9(30 \%)$ & $15(50 \%)$ \\
10.0 & $21(70 \%)$ & $30(100 \%)$ & - & - \\
12.0 & $27(90 \%)$ & $30(100 \%)$ & - & - \\
\hline
\end{tabular}

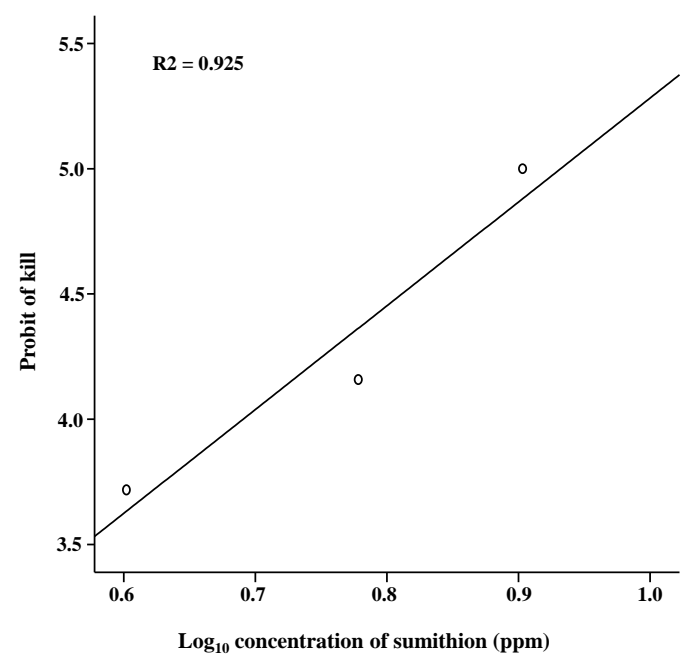

Figure 1.Graph showing the relationship of probit of kill with $\log _{10}$ concentration of sumithion used to deduce the LC50.

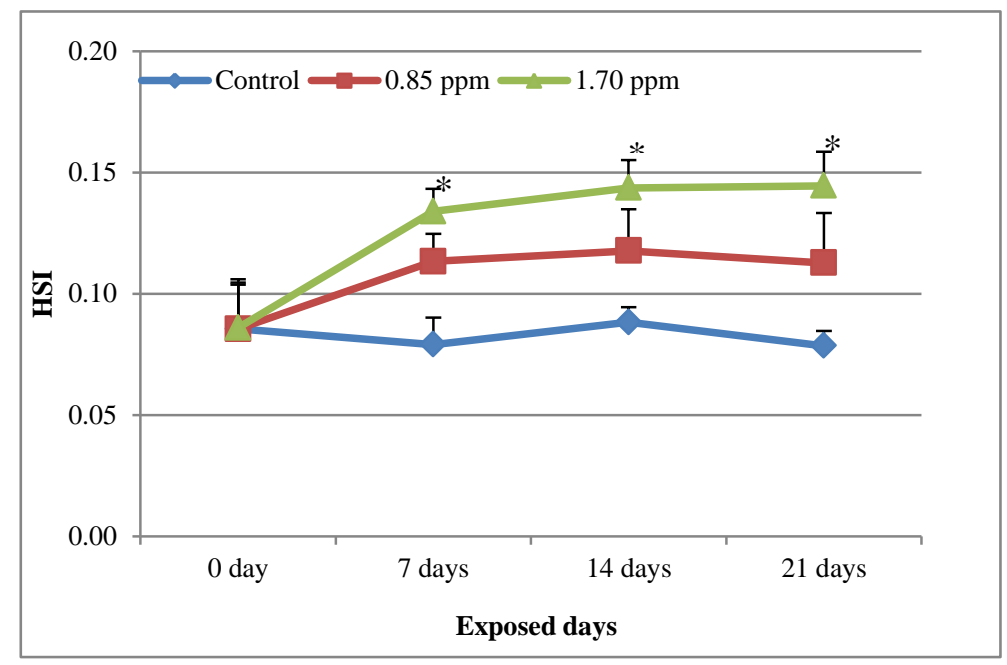

Figure 2. Changes in hepatosomatic index (HSI) of common carp exposed to sumithion for a period of 21 days. The HSI (means \pm SEM; $n=6$ ) were statistically analyzed and found to be significant $(P<0.05)$ in higher concentration (1.70 ppm) compared to control at 7, 14 and 21 days of exposure. Asterisk (*) indicate the statistically significantly different $(P<0.05, n=6)$. 


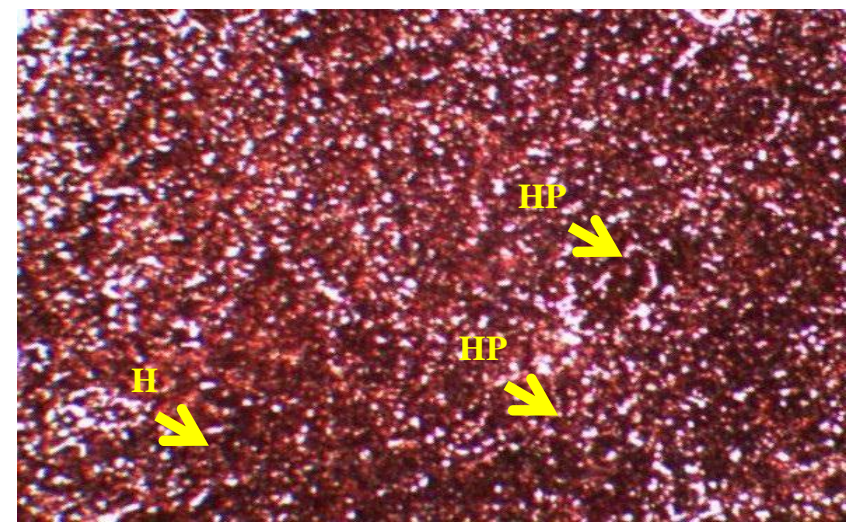

Figure 3. Showing normal histology of liver in control group; hepatocytes (H) and hepatopancreas (HP) are regular form and systematically arranged. Stained with $\mathbf{H} \& \mathbf{E}$.
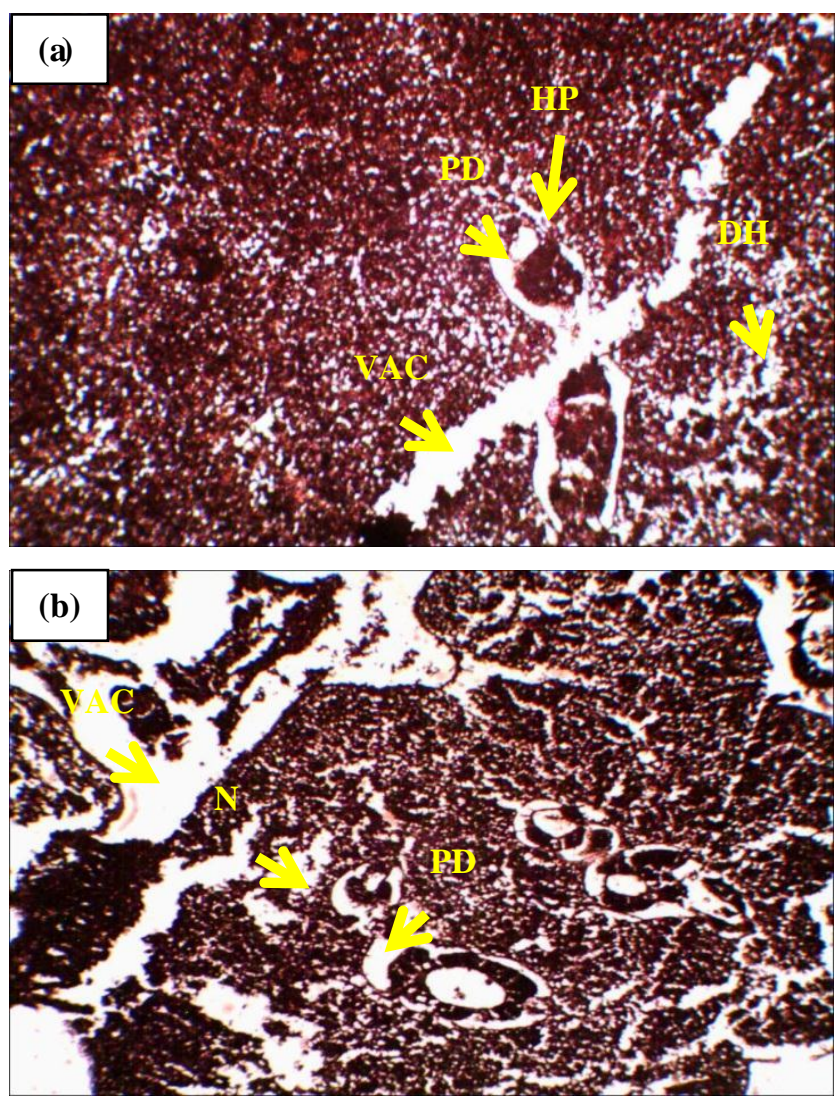

Figure 4. Histological changes of liver after 7 days exposure of sumithion at (a) 0.85 ppm, showing extensive necrosis $(\mathrm{N})$, patchy degeneration (PD),degenerated hepatocytes (DH) and vaculation (VAC); (b) $1.70 \mathrm{ppm}$, showing severe necrosis, degenerated hepatocytes and extensive vaculation. 

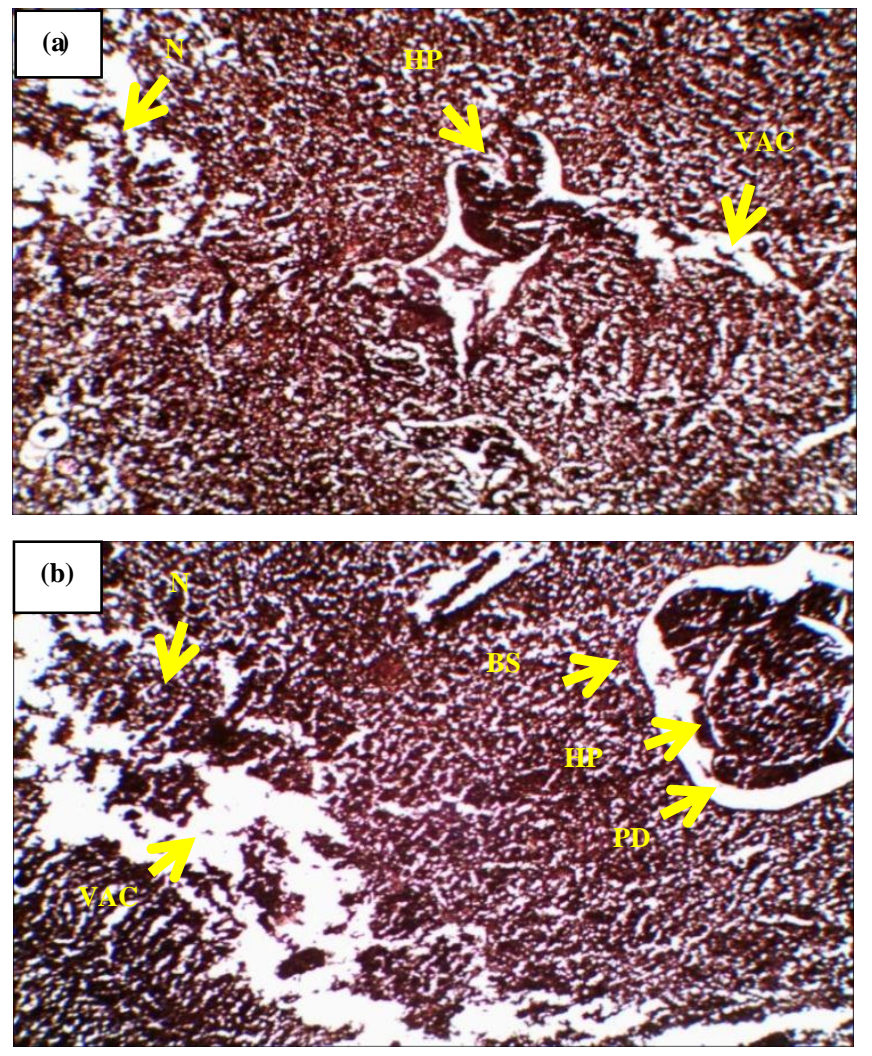

Figure 5. Histological changes in liver after 14 days exposure of sumithion at (a) $0.85 \mathrm{ppm}$ - showing huge necrosis and vaculation (VAC); (b) 1.7 ppm - showing severe necrosis, blood spilling (BS) and extensive vaculation.
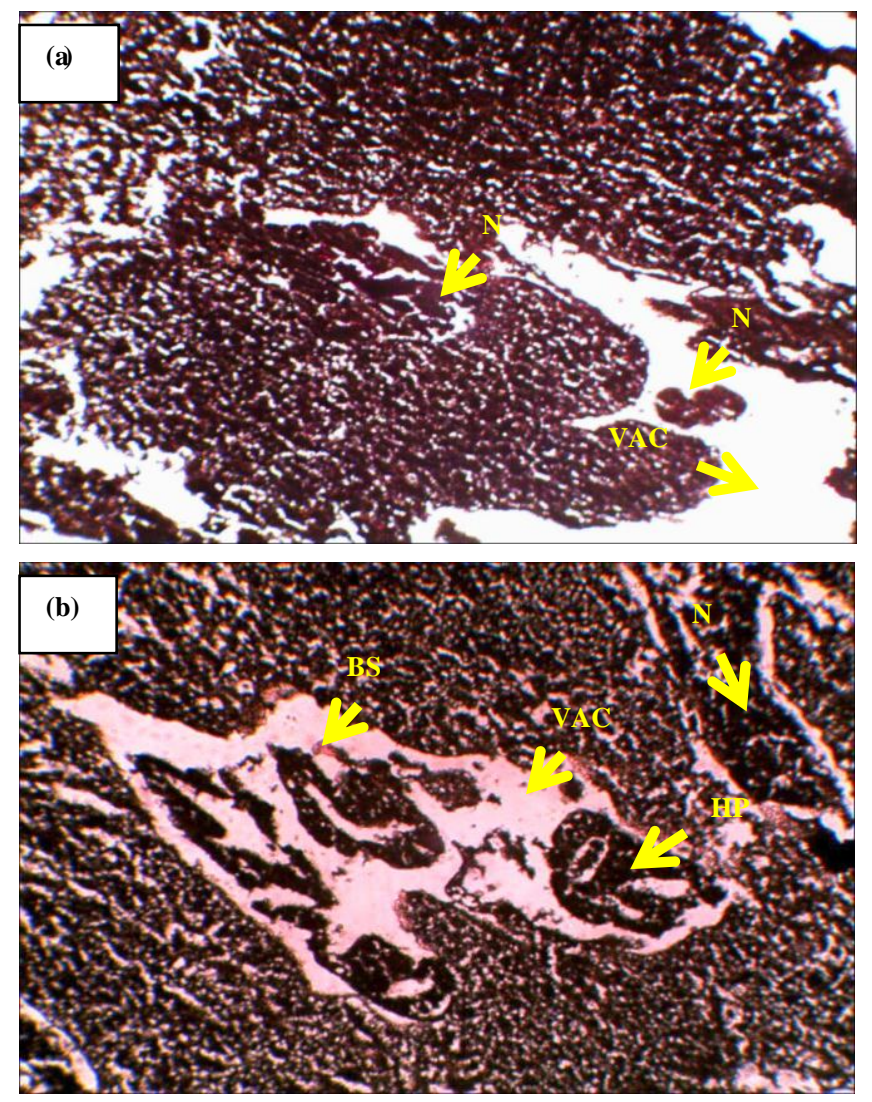

Figure 6. Histological changes in liver after 21 days exposure of sumithion at (a) $0.85 \mathrm{ppm}$ - showing huge necrosis and vaculation (VAC); (b) 1.7 ppm - showing severe necrosis, blood spilling (BS) and extensive vaculation. 


\subsection{Effects of sumithion on liver morphology}

Effects of sumithion on histoarchitecture of liver were analyzed by histology. The hepatocytes and other cells of the liver in control groups $(0 \mathrm{ppm})$ were normal and systematically arranged (Figure 3$)$. Several changes, such as necrosis $(\mathrm{N})$, patchy degeneration $(\mathrm{PD})$, degenerated hepatocytes $(\mathrm{DH})$, vaculation (VAC) and blood spilling (BS)were found in both (0.85 and $1.70 \mathrm{ppm})$ concentrations (Figures 4, 5 and 6). The intensity of the sehistoarchitectural changes wasmore severe in higher dose and exposure time. These changes may be due to direct toxic effects of sumithion on hepatocytes, as the liver is the site of detoxification of all types of toxins and chemicals (Parikh et al., 2010). The intensity of these histoarchitectural changes was more severe in higher dose and exposure time indicating that this pesticide has long-term effects on fish body. Parallel observations have also been reported in Heteropneustes fossilis exposed to Diazinon (Kabir and Begum, 1978), Channa punctatus exposed to Endrin (Shastry and Sharma, 1979), Brachydanio rerio exposedto Dimethoate 500 (Rodrigues and Fanta,1998), Neotropical fish with various pesticides (Camargo and Martinez, 2007), and Tilapia zillii and Soleavulguris (Mohamed, 2009). In our previous study, we demonstrated histological changes in liver of this fish species exposed to organophosphate pesticide Malathion (Sharmin et al., 2015). The hepatocytes exhibited reduction in their size and peripheral accumulation of cytoplasm after 20 days of exposureto organophosphate pesticide, Nuvan in the catfish Clarias batrachus (Shukla et al., 2005). Therefore, considering the previous observations, the present study revealed that sumithion is toxic for fish and alter the physiological functions of their body.

\section{Conclusions}

To know the toxicological effects of an organophosphorous pesticide sumithion on fish, we examined the effects of sumithion on HSI and histoarchitecture of liver in common carp. The insecticide sumithion exhibited potential toxicity to common carp in sub-lethal concentrations, causing noticeable changes in HSI along with several histological changes of liver. Sumithion showed more toxicity as increased dose and exposure time. Common carpcan be regarded as a bioindicator of environmental contamination and can be used as a model for toxicological testing. The findings of this study provide a warning that the indiscriminate use of sumithion can affect the structural integrity of the liver of fish, causing various disturbances in health and wellness in fish farming systems.

\section{Acknowledgements}

This work was supported by a grant of Impact of Aquaculture Drugs and Chemicals on Aquatic Ecology and Productivity Project (IADCAEPP) provided by Bangladesh Fisheries Research Institute (BFRI), Mymensingh2201, Bangladesh.

\section{Conflict of interest}

None to declare.

\section{References}

Ahmed SI, MK Ahmmed, SK Ghosh, MM Islam and M Shahjahan, 2015. Histo-architectural changes of intestinal morphology in Zebra fish (Danio rerio) exposed to Sumithion. Res. Agric. Livest. Fish., 2: 499506.

Camargo MM and CB Martinez, 2007. Histopathology of gills, kidney and liver of a Neotropical fish caged in an urban stream. Neotrop. Ichthyol., 5: 327-336.

Durkin PR, 2008. Malathion; Human Health and ecological risk assessment. Final report submitted to Paul Mistretta, PCR, USDA/Forest Service, Suthern region, Atlanta Georgia. SERA TR-052-02-02c; p. 325.

Faria IR, AJ Palumbo, TL Fojut and RS Tjeerdema, 2010. Water quality criteria report for Malathion. Phase III: Application of the pesticide water quality criteria methodology. UCDAVIS, 7; p. 64.

Gernhofer M, M Pawet, M Schramm, E Müller and R Triebskorn, 2001. Ultrastructural biomarkers as tools to characterize the healthstatus of fish in contaminated streams. J. Aqua. Eco. Stress Recov., 8: 241-260.

Hossain S, MH Khatun, MK Rahman and M Shahjahan, 2015. Impacts of sumithion on blood glucose and some hematological parameters in common carp. Int. J. Environ., 5: 8-13.

Kabir SMH and R Begum, 1978. Toxicity of three organophosphorus insecticides to Singhi fish Heteropneustes fossilis (Bloch). Dhaka Univ. Stud., 26: 115-122.

Kolaja KL, DE Stevenson, JT Johnson, EFJ Walborg and JE Klaunig, 1996. Subchronic effects of dieldrin and phenobarbital on hepatic DNA synthesis in mice and rats. Fundam. Appl.Toxicol., 29: 219-228. 
Maheswari Devi K, V Gopal and R Gopal, 1991. Liver somatic index of C. striatus as a biomonitoring tools, heavy metals and pesticides toxicity. J. Ecotoxicol. Environ. Monit.,1: 25-27.

Mohamed FA, 2009. Histopathological studies on Tilapia zilliiand Soleavulgurisfrom Lake Qarun, Egypt. World J. Fish and Marine Sci., 1:29-39.

Parikh PH, A Rangrez, R Adhikari-Bagchi and BN Desai, 2010. Effect of dimethoate on some histoarchitecture of freshwater fish Oreochromis mossambicus (Peters, 1852). The Bioscan, 5: 55-58.

Pathiratne A and SG George, 1998. Toxicity of Malathion to Nile tilapia, Oreochromis niloticus and modulation by other environmental contaminants. Aqua.Toxicol.,43: 261-271.

Pimpao CT, AR Zampronio, DE Silva and HC Assis, 2007. Effects of deltamethrin on hematological parameters and enzymatic activity in Ancistrus multispinis (Pisces, Teleostei). Pesticide Biochem. Physiol., 88: 122-127.

Rahman MS, M Shahjahan, MM Haque and S Khan, 2012. Control of euglenophyte bloom and fish production enhancement using duckweed and lime. Iranian J. Fish. Sci., 11: 358-371.

Rodrigues EL and E Fanta, 1998. Liver histopathology of the fish Brachydanio rerio Hamilton-Buchman after acute exposure to sublethal levels of the organophosphate Dimethoate 500. Revtabras Zool., 15:441-450.

Salam MA, M Shahjahan, S Sharmin, FHaque andMK Rahman, 2015. Effects ofsub-lethal doses of an organophosphorous insecticide sumithion on somehematological parameters in common carp, Cyprinus carpio. Pakistan J. Zool., 47:1487-1491.

Shahjahan M, MF Kabir, KA Sumon, LR Bhowmik and H Rashid, 2016. Toxicity of organophosphorous pesticide sumithion on larval stages of stinging catfish Heteropneustes fossilis. Chinese Journal of Oceanography and Limnology. doi.org/10.1007/s00343-016-5173-3.

Sharmin S, M Shahjahan, MA Hossain, MA Haque and H Rashid, 2015. Histopathological changes in liver and kidney of common carp exposed tosub-lethal doses of Malathion. Pakistan J. Zool., 47:1495-1498.

Shastry KV and SK Sharma, 1979. Endrin induced hepatic injury in Channa punctatus (Ham.). Indian J. Fish., 26:250-253.

Shukla S, SK Dass and DN Saksena, 2005. Effect of sublethal exposure of an organophosphorus pesticide, Nuvan on liver of catfish, Clarias batrachus. Nature Environ. Polln. Technol., 4:447-452.

Talukdar MZH, M Shahjahan and MS Rahman, 2012. Suitability of duckweed (Lemna minor) as feed for fish in polyculture system. Int. J. Agril. Res. Innov. \& Tech., 2:42-46.

Teh SJ, SM Adams and DE Hinton, 1997. Histopathological biomarkers in feral freshwater fish populations exposed to different types of contaminant stress. Aqua. Toxicol., 37: 51-70.

Thomson WT, 1989. Agricultural Chemicals. Book I: Insecticides. Thomson Publications, Fresno, CA; p. 120.

Thophon S, M Kruatrachue, ES Upatham, P Pokethitiyook, S Sahaphong and S Jaritkhuan, 2003. Histopathological alterations of white seabass, Lates calcarifer, in acute and subchronic cadmium exposure. Environ. Polln., 121: 307-320.

Uddin MH, M Shahjahan, AKMR Amin, MM Haque, MA Islam and ME Azim, 2016. Impacts of organophosphate pesticide, sumithion on water quality and benthic invertebrates in aquaculture ponds. Aquaculture Reports, 3: 88-92.

Ventura BC, DF Angelis, AM Maria and M Morales, 2008. Mutagenic and genotoxic effects of the Atrazine herbicide in Oreochromis niloticus (Perciformes, Cichlidae) detected by the micronuclei test and thecomet assay. Pestic. Biochem. Physiol., 90: 42-51.

White INH, AR Mattocks and WH Butler, 1973. The conversion of the pyrrolic derivatives in vivo and in vitro and its acute toxicity to various animal species. Chem. Biol. Interact., 6: 207. 